\title{
Genesis 27:27-29 in the face of the popular Christian concept of blessing in Nigeria
}

\begin{tabular}{|c|c|}
\hline \multicolumn{2}{|c|}{$\begin{array}{l}\text { Authors: } \\
\text { Mary J. Obiorah } \\
\text { Favour C. Uroko } \\
\text { Fan }\end{array}$} \\
\hline \multicolumn{2}{|c|}{$\begin{array}{l}\text { Affiliations: } \\
{ }^{1} \text { Department of Religion and } \\
\text { Cultural Studies, Faculty of } \\
\text { the Social Sciences, University } \\
\text { of Nigeria, Nsukka, Nigeria }\end{array}$} \\
\hline \multicolumn{2}{|c|}{$\begin{array}{l}{ }^{2} \text { Department of New } \\
\text { Testament Studies and } \\
\text { Related Literature, Faculty of } \\
\text { Theology and Religion, } \\
\text { University of Pretoria, } \\
\text { Pretoria, South Africa }\end{array}$} \\
\hline \multicolumn{2}{|c|}{$\begin{array}{l}\text { Research Project Registration: } \\
\text { Project Leader: E. van Eck (D) } \\
\text { Project Number: } 2400030\end{array}$} \\
\hline \multicolumn{2}{|c|}{$\begin{array}{l}\text { Description: } \\
\text { This research is part of the } \\
\text { research project 'Socio- } \\
\text { cultural Readings', directed } \\
\text { by Prof. Dr Ernest van Eck, } \\
\text { Department of New } \\
\text { Testament Studies and } \\
\text { Related Literature, Faculty of } \\
\text { Theology and Religion, } \\
\text { University of Pretoria. }\end{array}$} \\
\hline \multicolumn{2}{|c|}{$\begin{array}{l}\text { Corresponding author: } \\
\text { Favour Uroko, } \\
\text { favour.uroko@unn.edu.ng }\end{array}$} \\
\hline \multicolumn{2}{|c|}{$\begin{array}{l}\text { Dates: } \\
\text { Received: } 11 \text { Jan. } 2019 \\
\text { Accepted: } 15 \text { May } 2019 \\
\text { Published: } 23 \text { Oct. } 2019\end{array}$} \\
\hline \multicolumn{2}{|c|}{$\begin{array}{l}\text { How to cite this article: } \\
\text { Obiorah, M.J. \& Uroko, F.C., } \\
2019, \text { 'Genesis } 27: 27-29 \\
\text { in the face of the popular } \\
\text { Christian concept of blessing } \\
\text { in Nigeria', HTS Teologiese } \\
\text { Studies/Theological Studies } \\
75(3) \text {, a5383. https://doi.org/ } \\
\text { 10.4102/hts.v75i3.5383 }\end{array}$} \\
\hline \multicolumn{2}{|c|}{$\begin{array}{l}\text { Copyright: } \\
\text { (c) 2019. The Authors. } \\
\text { Licensee: AOSIS. This work } \\
\text { is licensed under the } \\
\text { Creative Commons } \\
\text { Attribution License. }\end{array}$} \\
\hline Read online: & \\
\hline 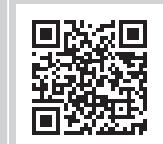 & $\begin{array}{l}\text { Scan this QR } \\
\text { code with your } \\
\text { smart phone or } \\
\text { mobile device } \\
\text { to read online. }\end{array}$ \\
\hline
\end{tabular}

Conspicuous in the Old Testament (OT) is the literary genre of blessing that is often construed in poetic forms. They are of various types and were significant to their initial audience. A careful analysis of their texts and contexts is indispensable for a correct understanding of their message. Conversely, in our times, these texts and their contents are misinterpreted for some subjective goals, which deviate greatly from what one can perceive as their original meaning and intention. Misinterpretation and incorrect application of Biblical texts of blessings thrive in a society like ours where ills are perpetrated under the guise of religion. The text of Genesis 27:27-29, carefully inserted in the patriarchal narratives, contains a type of OT blessings portraying parents' wishful desires for their offspring; this is common to all human cultures. It is chosen as a springboard for the study of other parental blessings in the OT. Employing a literary analysis with particular attention to the functions of poetic devices in the text, the study aimed at understanding the message contained therein and its relevance to our contemporary society.

Keywords: Blessing; Esau; Genesis 27; Isaac; Jacob; Patriarch; Rebecca.

\section{Introduction}

Expressions of the divine-human relationship prevalent in all parts of the Sacred Scripture take varied forms, which include: obedience to God's law revealed in words and deeds and embedded in natural laws; abhorrence of created things worshipped as gods; and various forms of prayers acknowledging humans' dependence on God. These are observed by human beings with the intention of remaining in relationship with God who has revealed himself. At the background of the teaching of the Old Testament (OT) is this awareness of the Being that created all, who sustains and cares for human welfare. It is necessary to constantly recognise this and maintain this relationship in all circumstances; it is life to do this, and any form of deviation leads to disaster.

The concept of blessing, which is the focus of this study, is best understood in the context of human expressions of the divine-human relationship because of the underlying perception of blessing as God's unconditional gift. In the Hebrew Bible, the verbal root of all cognates of the Hebrew word for blessing is brk, which also means 'kneel'. This second connotation most probably refers to the posture that the recipient of blessings takes in the act of blessing. The verb appears often in piel conjugation, occurring more frequently in the Book of Genesis and in the Psalms (Scharbert 1999:267). The adjectival form is the qal passive, bārûk [blessed], from the same root. This root is frequent in Genesis because blessing is a key concept in this book, especially in the formation of its structure (Champlin 2017).

Blessing is a human expression of the divine-human relationship; specifically, it is the human understanding of utter dependence on God. It is God who blesses, even when a blessing is pronounced by human beings. Humans invoke God's blessing on another; or they bless another in the name of God. The contents of blessing or what human beings pray or wish for another, such as fertility of the land, animals, human beings, land or long life, are God's unconditional gifts. In blessing, human beings wish that another receives these. They recognise the divine origin of these gifts and thus pray that God may grant them to the prospective recipient(s) of blessing.

The concept of blessing in our contemporary popular Christian praxis seems to lose sight of the divine origin of blessings as God's unconditional gifts. God blesses not because of what human beings give him but because of his generous love. We cannot procure divine blessing with our wealth; whatever riches we have are his gifts to us. God's blessings do not depend on the magnitude of what we think we can give him. Texts from the Scripture are often cited to buttress the argument that affluence considered as divine blessing accrued to human beings because of 
their generosity to God. The real message of these texts when interpreted in their contexts disproves this trendy concept of blessing.

The text of Genesis 27:27-29 relates to the words of blessing of Isaac on his son Jacob. The narratives before and after this blessing contain strife in the family of this patriarch, strife that commenced while the twin sons of Isaac were still in the womb. Isaac wanted to thwart the choice of the younger son motif common in the OT, but the alertness and smartness of the mother, Rebecca, saved the situation.

The efficacious role of Israel's matriarchs (Zucker 2011:46-47) propelling the history of their nation is glaringly portrayed in the narratives. Isaac is depicted as the one deceived, but there is more to these apparent presentations in the story. Of interest in this family story are the words of blessing pronounced by the dying father, who was an authority in his household. Deathbed blessing is a special kind of blessing that is common in many cultures of the world, particularly in Israel's surrounding cultures. The dying person imparts God's blessings on loved ones and makes some prophecies concerning their future. The key message of the content of this blessing can be deduced from the introductory part of Isaac's words: 'the Lord has blessed' (v. 27) and 'may God give you ...' (v. 28). It was God who blessed, even though the words were pronounced by Isaac.

Generally, blessings in the OT are presented in a poetic form. In the analysis of the chosen text of this article, particular attention is given to the poetic techniques employed by the writer. The tripartite structure of this presentation begins with a study of Genesis 27:27-29; this precedes subsequent discussions on blessings in the OT as the general context of this text, and the dialectic of the pericope in the light of the popular Christian concept of blessings.

\section{Understanding Genesis 27:27-29}

Fascinatingly, it is reflecting on the saga of Isaac's family that reached a decisive point in the conferral of blessing on the younger son of the family instead of the expected heir to that blessing. Isaac's feelings of regret and treason (Zucker 2011) after blessing Jacob elucidate further the undue passivity of this patriarch who was a sharp contrast of his wife Rebekah. Did he forget the prophecy the divine oracle pronounced when the twin brothers were still in the womb? It is instructive to observe that it was the mother who consulted the Lord, and the destinies of each of them were communicated before they were born. The poetic words of the Lord on this, articulated in Genesis 25:23, convey the hostility that would permeate the relationship between the two brothers. Both would be eponyms of two nations that would be marked by enmity. One of them would be stronger, and the elder would be subservient to the younger. Their mother, who experienced the struggle of the two babies in her womb (cf. Gn 25:22), sought and received, of course with the knowledge of her husband, the divine proclamation as interpretation of the infants' strife within her; she most probably treasured all these in her heart as she watched her sons mature in age.

Prior to Isaac's deathbed blessing, Esau had ironically anticipated his ordeal by selling his birthright for a meal of 'bread and lentil stew' (Gn 25:29-34). 'Thus Esau despised his birthright' (Gn 25:34) (Bulka 1990:100-104). Was the passive father Isaac not aware of these events unfolding in his own house when he planned the inheritance of the firstborn for one who was not so much concerned about it? The narrator highlighted something that Isaac and Esau shared in common: the pleasure of eating. In fact, 'Isaac loved Esau, because he was fond of game, but Rebekah loved Jacob' (Gn 25:26). The mother loved the younger son, probably because of the prophecy made about him, and also because Jacob 'was a quiet man, living in tents' (Gn 25:27). In other words, he was very close to the mother in the house, unlike his brother who was a hunter in the field.

Securing the father's deathbed blessing for Jacob was paramount to the mother because of the significance of this blessing in human society, and because of the mother's acute perception of the future of the two brothers. She was quite opposite of her husband's apparent indifference to the divine plan and human customs. Esau had already proved his worth, generating unrest in the family when he married from outside the family lineage; he married two Hittite women (cf. Gn 26:34), 'and they made life bitter for Isaac and Rebekah' (Gn 26:35). In his own time, Abraham forestalled such confusion in his family when he planned for Isaac's marriage from their relations, even when it entailed a very long trip to bring the bride (cf. Gn 24). At the age of 40 (cf. Gn 26:34), Isaac's sons had not yet formed their individual families. Would one blame Isaac for neglect of parental duty? Can one hold Isaac responsible for Esau's mistake of marrying two Hittite women? 'But it is difficult to remain inactive when a great evil is about to happen, and the means of preventing or averting it seems to be at hand' (Canlish 1979:460).

Rebekah had to eschew further oversight of her husband by setting history right (Rackman 1994:37-45).

Absurdity in Isaac's intention of giving deathbed blessing only to the son he loved, who was not even part of the divine plan, must have impelled Rebekah to skilfully thwart the plan. Her action may appear like treason, but it was God's plan for the family and ultimately for the ensuing nation of Israel, a plan that Isaac could not perceive, or he did but could not summon the courage to execute it. The author of the New Testament Letter to the Hebrews seems to understand the concern of Rebekah when he thus articulates in this letter: 'See to it that no one becomes like Esau, an immoral and godless person, who sold his birthright for a single meal' (Heb 12:16).

The contents of the blessing that Isaac planned for Esau are actually for Jacob, judging from the prophetic oracle 
preceding their birth. The poetic layout of this blessing in Hebrew is stated as:

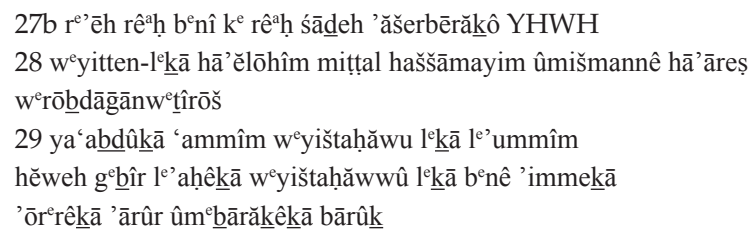

The Hebrew version of these few poetic lines is well preserved and one does not encounter difficulties rendering them into English. The translation of the writer reads:

$27 \mathrm{~b}$ See, the smell of my son is like the smell of a field that the Lord has blessed.

28 May God give you of the dew of heaven, and of the fatness of the earth

and plenty of grain and wine.

29 May peoples serve you, nations bow down to you.

Be lord over your brothers may your mother's sons bow down to you.

Cursed be those who curse you and blessed be those who bless you!

The entire verse 27 serves as an introduction to this blessing; its first part, not included above, is in prose, describing the actions of Jacob, disguised as Esau, and Isaac before he began his solemn blessing. Thus, verse 27a states two actions of Jacob: he came near and kissed his father; and a basic action of the dying father: Jacob came near and kissed Isaac and the father smelled the smell of his son's garments. The keyword, smell, construed as a verb and a substantive in this chain of actions becomes also a keyword in his speech proper in verse $27 \mathrm{~b}$.

Verse $27 \mathrm{~b}$, on the other hand, is the immediate introduction, flowing from verse $27 \mathrm{a}$, to the words of the blessing.

In point of fact, the blessing proper is presented in verses 28-29, Verse 28 contains the first set of blessings and they are on the abundance of earthly things. The three components are interrelated: the first, 'dew of heaven', is manifested in the second component: 'fatness of the earth'; and the phrase, 'plenty of grain and wine' is in apposition to what comes immediately before it. It explains what 'fatness of the earth' entails. In other words, 'plenty of grain and wine' sheds light on the metaphoric use of 'fatness of the earth' (Watson 1995:133). One notes the use of waw at the beginning of the first stich; it is not translated above because it does not have any translation value as such; its function is to indicate the jussive (yitten 'may he give', 'would that he gave!') more clearly (Joüon \& Muraoka 2006). This verse is a major segment in this poem because the content of the next verse 29 focusses on a different subject or aspect of the blessing. Verse 29 exhibits a common feature of Hebrew poems; the first two lines have two pairs of synonymous parallelism in which the second stich of each poetic line intensifies the first stich. The third line of verse 29 contains a pair of antithetic parallelism, which makes it different from the two preceding lines of this verse. It is on curse and blessing with regard to other persons' attitude towards the recipient of the blessing. Therefore, the structure of Isaac's deathbed blessing can be summarised in this way (Arnold 2009:246):

Introduction (v. 27b)

First set of blessing on fertility of the land (v. 28)

Second set of blessing on dominion over all nations and siblings (v. 29a-b)

Fate of potential enemies and friends (v. 29c)

Verse $27 \mathrm{~b}$ begins with an initial interjection, in an imperative form ( $r^{\prime}$ èh 'see', 'behold', 'Ah'), employed here 'to attract attention to what is perceived by a speaker, narrator or by a character in a narration as new, important or surprising' (Joüon \& Muraoka 2006). In this context, it is what is perceived by the speaker, for Isaac expressed what he felt. The smell of his son was comparable to the smell of a field blessed by the Lord. It was his mental understanding of Esau whom he was expecting. Rebekah planned it so that Jacob would have all the traits of Esau for she made Jacob put on the garments of his elder brother, who was 'a man of the field' (Gn 25:27). The smell of the field was important to Isaac because it assured him of the recipient of his blessings, whom he understood to be Esau. Again, this smell was also important to Rebekah because it was something that she employed to convince Isaac that it was Esau he felt and perceived.

However, there is more to Isaac's exclamation than a mere perception of the smell of a field, for the phrase 'a field that the Lord has blessed' is a fitting prelude to the first set of blessings that focusses on the abundance of the produce of the earth: grain and wine. When this is read in the context of the history of Israel, their sedentary phase comes to mind (Westermann 1985:440). Furthermore, the phrase in verse $27 \mathrm{~b}$ introduces God as the source of every blessing; when human beings bless, they bless in the name of God. They are the instruments through which God imparts his blessings.

It is God who blesses; this is a characteristic of blessings in the OT and it is evident in Isaac's blessing as we read in the first set of blessings in v. 28. Isaac states from the onset that the aspirations expressed in v. 28 are from God. The Hebrew verbal root, brk, often in piel conjugation, for blessing, does not occur here; it is used in the introduction in verse $27 \mathrm{~b}$, and it will also occur in its recurrent passive blessing formula at the end of verse 29. The significance of the passive form, understood as a divine passive ('be blessed'), of this verb in blessings suggests that human beings do not have in themselves the power to bless. It is God who bestows the good wishes expressed by human beings (Scharbert 1999:303). Isaac took cognisance of this when he said 'May God give you ...' (v. 28). His blessing was made before the Lord and it was irrevocable (Scharbert 1999:289) (cf. Gn 27:33). Rebekah knew the implication and the nature of such blessings, and she did all in her power to secure it for the one whom God had already destined. In relating to Jacob Isaac's instructions to Esau (cf. Gn 27:4), the mother heightened the sacred and irrevocable character of the blessing (Alter 2008:14) by replacing 'that I may bless you before I die' with 'that I may bless you before the Lord before I die'. 
The contents of the blessing in verse 28 are intertwined. The first is the gift of 'the dew of heaven'; this expression, together with the phrase 'the fatness of the earth' in the next stich, occurs in an Ugaritic Baal Epic concerning the goddess Anath: 'She draws some water and bathes/Skydew, fatness of earth' (Pritchard 1969:136). This shows that 'an ancient blessing formula has been taken over after the settlement in Canaan' (Westermann 1985:441). In Hebrew, dew (tal) also means light rain; it is a symbol of fertility of the land (Otzen 1986:325). This explains why it can be used in the formula of blessing. In fact, 'dew' is an image of blessings (Uval 1998:117-118). On the other hand, absence of dew is a curse.

The second element of this blessing is 'fatness of the earth', which is an aftermath of 'the dew of heaven'.

The term 'fat' ( $\check{s} \bar{a} m \bar{a} n)$ in this context connotes a fertile land or field, made possible by rain. In the Hebrew Bible, this term occurs only in Genesis 27:28, 39 and Isaiah 28:1-4. The fertility of a land is seen in its produce, grain and wine, the third element of the blessings in verse 28. 'Grain and wine' are common elements in pronouncement of blessings (cf. Dt 7:13; 33:28) and in the lists of the produce of the land of Canaan (cf. Dt 28:51; 2 Ki 18:32; Hs 7:14; Jl $1: 10)$. In this first set of blessings, Isaac wished an abundance of riches for his son and these are more appropriate for Jacob than for Esau (Wenham 1994:209) because the descendants of Jacob settled as farmers in the land unlike the nomadic progenies of Esau (Snijders 1991:183). Did Isaac actually prepare this blessing for Esau? This adds to the enigma in this narrative.

In verse 29, we have another set of blessing, different from the content of verse 28. It has to do with dominion over other peoples and nations, and siblings. The synonymous parallelism of the first two poetic lines of this verse has been noted above. The initial waw of the second stich in 29a is deliberately omitted in the translation because it is epexegetical waw, which 'serves to clarify or specify the sense of the preceding clause' (Waltke \& O'Connor 1990:652). Together with the sense of the synonymous parallelism, this waw sheds more light on the meaning of 'May peoples serve you'. It is made more explicit in 'may nations bow down to you'. Both stiches are reminiscent of the divine oracle pronounced before the birth of the two brothers: one shall be stronger than the other and the elder shall serve the younger ( $\mathrm{Gn}$ $25: 23$ ). The sense of this extends to v.29b, which is also a synonymous parallelism. Jacob is to be the lord over his brothers or his mother's sons shall bow down to him. This brings to mind the dreams of Joseph and their realisation when he became an Egyptian official. If Esau was the eponym of the Edomites, it is most likely that there is an allusion to the Israel's subjection of Edom, even though the plural forms of 'peoples and nations' in the text seems to make this an impossible suggestion (Westermann 1985:441). Isaac prayed in this blessing that his son would be in a position of authority and would not be subjugated by anyone.
The final poetic line ('Cursed be those who curse you and blessed be those who bless you!') of Isaac's words over Jacob is the same as we read in Numbers $24: 9 \mathrm{~b}$, the last line in Balaam's third oracle. There is a reflection of this in Genesis 12:3, albeit with some significant variations. Firstly, the order is different, for in Genesis 12:3, blessing comes before the curse, unlike in Genesis 27:29. Secondly, the source of the blessing and curse is more explicit in Genesis 12:3, it is the Lord speaking in the first person: 'I will bless ... and I will curse ...'. In Genesis 27:29, the passive forms of the verb embody the agent of the actions of bless and curse (Moberly 2009:168). Friends of the recipient of the blessings shared in his blissful state, whereas his enemies had their due reward. The ill-fate of those who would curse Jacob was that they would be separated from God's blessing (Champlin 2017), and those who would bless him would receive God's blessings.

With these words pronounced over Jacob, Rebekah faithfully achieved her desire to see the prophecy fulfilled and God's plan accomplished. When Esau insisted to be blessed by his father, a contrary pronouncement, almost a curse, was his lot. According to the narrative, Isaac actually accepted what appears like a defeat. His condition after he gave the blessing to the wrong person is sometimes compared to Abraham's test (Goodnick 1995:227). Isaac was tested and he was able to resolve his internal torment.

Therefore, despite his love for Esau, he summoned courage and explained to his elder son the irrevocability of the blessing he gave to Jacob.

\section{Genesis 27:27-29 in the context of blessings in the Old Testament}

Rebekah's solicitude for Isaac's deathbed blessing as well as Isaac's desire to bestow this blessing on Esau confirm that 'fundamental to the whole story is the conviction of the efficacy of the deathbed blessing; that what the patriarch says before he dies determines the destiny of his descendants' (Wenham 1994:216). Isaac's blessings bear the characteristics of the blessing formula in the OT. Foremost in this formula is the indication that it is Yahweh who blesses; human beings bless 'by wishing and praying that Yahweh will bless' (McKenzie 1965:98). This is clearly stated in Isaac's blessing before he uttered the words of the blessing.

The importance of the blessing was also elucidated by Rebekah when she related to Jacob that the blessing would be made in the Lord's presence (Gn 27:7). Further examples (Brown 1996) of the divine origin of the blessings are found in Jacob's blessing of his sons (Gn 49:25); Noah blessed his sons Shem and Japheth (Gn 9:26); Melchizedek blessed Abraham (Gn 14:19) (Champlin 2017); Eli blessed Elkanah and Hannah (1 Sm 2:20); David blessed his people (2 Sm 6:18); Solomon's words of blessing on his people at the dedication of the newly erected temple of Jerusalem $(1 \mathrm{Ki} 8: 14 ; 55)$. In all these, it is made clear that the blessings pronounced are from God. 
Blessings are imparted by persons who possessed blessings themselves, usually persons in authority such as the priest, the king or the head of a family. It is effective when uttered by these categories of persons because of their positions and status in the society. Isaac as the head of the family had this singular privilege to bless his son. Besides being the head of his family, he was also blessed by God (cf. Gn 26:3-4). As someone blessed and possessing blessing, he could invoke God's blessing and transmit it to another. Isaac's blessing was of great importance because it was a deathbed blessing whereby he communicated his own life, strength and authority (Mckenzie 1965:98). Such a blessing had a factitive impact for in pronouncing someone as blessed (bārûk), the addressee was made blessed (Keller 1997:266, 272). Isaac actually made Jacob blessed when he said those words over him. It was the ardent desire of his mother who knew that Jacob, and not Esau, had been destined for this blessing. Similar blessings, farewell before death, are found in Genesis 48, where Jacob blessed the sons of Joseph; Jacob addressed each of his sons (cf. Gn 49), and this was more of prophecies on the future of each of his sons; Moses blessed the Israelites before he died (cf. Dt 33).

Isaac's desire to impart this on the son he loved was common in the ancient Near East as one reads in an analogous patrilineal culture of Nuzi, where the oldest son was expected to be the heir and to receive the divine patronage of the household (Matthews \& Benjamin 1997:49). The supreme authority of the family was transferred to the eldest son (Gerstenberger 2002:48). In the light of this, one can understand why Isaac desired this for his elder son, but Esau gave up his birthright as the eldest son and lost this privilege. He was lost to the family as a potential heir and became a foreign entity (Birch et al. 2005:81).

The contents of the blessings include the gift of fertility, which can be of land, animals and human beings; well-being; and victory over the enemies. These were also Isaac's wishes for his son. He prayed for 'the dew of heaven' that makes fatness of the earth possible, exemplified in 'plenty of grain and wine'. Dominion over peoples and nations could form part of well-being that is included in the abundance of harvest. Victory over the enemies can be deduced from the formula of the curse at the end of Isaac's blessing: 'cursed be everyone who curses you' (Gn 27:29).

Amidst the multifaceted features of the narrative surrounding the reception of parental and deathbed blessing in Isaac's house emerges conspicuously the concept of the divine source of blessings in the OT. It is the hinge on which hang the varying actions of persons connected with the paternal blessing that Isaac intended to grant his elder son, but which the younger son eventually obtained. The narrative contains a common practice seen in all human cultures: parents, guardians, relatives wishing their loved ones well and praying for their well-being, particularly for a prosperous future. In the narrative, the potent background role of women in the history of Israel, especially in the patriarchal stories, is very much highlighted. Furthermore, the motif of divine preference for the younger son in place of the elder is dramatised. The narrative also features the natural human phenomenon of strife within a family. From among all these diversified OT motifs, the concept of blessing with all its characteristics is elucidated.

Blessing, as a religious act, has both vertical and horizontal dimensions. Its vertical dimension consists in the fact that in every act of blessing, God is the principal agent and the contents of blessing are exclusively divine gifts to human beings and the rest of creation. When a person blesses another, he or she entreats God to bestow these gifts on the prospective recipient. Apart from the explicit indication in Isaac's words of blessing that these gifts are from God, a reflection on his prayer shows that his points of prayer are invariably from God and beyond human capacity. 'The dew of heaven', which he asked for his son, cannot come from any human being, for God is always its source. In the same way, 'the fatness of the earth', which is a consequence of the divine gift of 'the dew of heaven', is also from God. Dominion and lordship over peoples and nations are possible only through divine intervention. Similarly, the passive form of 'cursed be' and 'blessed be' in verse 29 manifests an underlying divine passive, indicating God as the principal agent.

Blessing bears a horizontal dimension intrinsically linked with its vertical dimension. The human person who blesses another does so in the name of God. The person wishes the recipient well. In other words, it is a sign of benevolence towards another. An enemy might not naturally do this. If blessing has vertical and horizontal dimensions, it reflects the two arms of every religious praxis. These two dimensions are our relationship with God and our relationship with fellow human beings. Words of blessing pronounced by a person over another unite these two dimensions in a religious belief that God alone is the source of blessings on human beings and that beneath our love for others is a strong belief in God.

From these observations on the act of blessing, one notes that blessing is a subtle act of praise of God. When a person blesses another, this human agent of blessing praises God. This is because the gifts the person asks of God to give to another belong to God alone. Therefore, the agent praises God who alone has these gifts in himself and who alone can give them to human beings. The gift of 'the dew of heaven', which Isaac asked for his son, belongs to God. Isaac believed that God could give this and other gifts to his progeny; thus, he praised God as he, Isaac, asked for these gifts.

\section{Genesis 27:27-29 and the popular Christian concept of blessing}

In the light of the above observations on the Biblical concept of blessing, particularly in the context of Genesis 27, the popular Christian understanding of blessing in our society appears as an aberration in the guise of religiosity. It is 
an aberration generated first and foremost from the wrong interpretation of the Sacred Scripture.

When Biblical texts are extracted and interpreted outside of their contexts, the message is very often lost.

This is true of many passages where blessings are mentioned. Incessant quest for material blessings, 'break-through', as we hear in many petitions, compel some to lose sight of the message of the Biblical texts. Both leaders and their followers scan through the Scripture for instances where persons are said to be blessed.

Frequently cited is the phrase, 'the blessings of Abraham' (Gn 28:4), which in our society has been turned into a popular song. The users visualise the possessions of Abraham and the countless promises from God (cf. Gn 12; 13:2).

Often overlooked are the qualities, particularly the faith proved in trials that the recipients of Biblical blessings experienced in their lives. No one wishes to undergo Abraham's trials, but rather to possess his blessings. Actually, behind the present-day craving for material blessings of varied forms is the wilful alienation from the core of the Christian faith, the Cross. Lack of faith in the salvific value of sacrifices in our lives as Christians is prevalent. We neglect the fact that Jesus whom we follow trod the path of suffering to glory.

Sufferings must be avoided at all costs! Genesis 27 is often interpreted as a model of chasing after blessing and grabbing it even with deceit. We have seen in the above narrative that the apparent deceit has much more to its meaning and message.

Excessive and frantic quest for blessing and 'break-through' everywhere and at all times in our context is greatly engendered by the life condition of our people. What appeals to the church followers in Nigeria is the promise of deliverance from poverty, spiritual problems, diseases and other problems through God's blessing (Mösch, Bello \& Hoffmann 2007). Many have very little to sustain themselves in life; therefore, they seek respite at every corner. Again, persons who are in positions to alleviate the sufferings of others exploit the little they have to live on. Dachen (2016) laments that Nigeria has been recognised as one of the most religious countries; however, most religious leaders and politicians capitalise on this to play the people against one another, especially when they stand to gain.

Human rights are violated with impunity. Loss of hope in those who should care drive many into utter despair, as they fall into the hands of self-acclaimed miracle workers who, in the same desperate life situation, make their living through deceit in the name of the Church. Pastors in Nigeria specify the amount of offerings they want and they use psychology and sugar-coated talks and preachings to democratically coerce their members into making the payments and claim their blessings, but on receiving the payments, these pastors would be busy acquiring private jets and landed property. According to Raymond (2016) reveals that a Nigerian pastor told his members:

We need N1 billion from 10 people. If you are one of them, please see my personal secretary after we finish today. We also need N100 million from those who can afford it, if you are in that category. Please see my personal Secretary as well. (p. 1)

Furthermore, Pastor Ifeanyi Okoli and his wife, Prophetess Ngozi Okoli, from God's Covenant Ministry, Ejigbo, Lagos, duped a widow who came to their church for God's blessings of her property worth four million naira (Izuekwe 2011).

Knowing that 'spoken words shape human life' (Brueggemann 2010:228) and that persuasive words of the Scripture can inevitably attract the uninformed to believe in trickery, miracle-workers make profuse use of the words from the Scripture. They make promises that appear real and prepare allies to fake real recipients of blessings. Their blessing is against the religious sense of blessing that a person asks of God for the well-being of another. In place of the underlying genuine love that characterises blessing in the Bible, one experiences the opposite.

Undue emphasis on human contribution to divine blessings manifests little understanding of the Biblical texts or misappropriation of the Scripture. Blessings, according to many Christians (especially persons who purport to be spiritual leaders or miracle workers), proceed from human efforts and are measured by what human beings are able to 'give' God in exchange. They claim these blessings as theirs and extort gullible poverty-stricken ones of their meagre possessions. Those who claim to possess blessings and distribute them to others deceitfully enrich themselves. They persuade their followers 'to sow seeds', pay tithes, fast and submit the proceeds of the fasting to the pastors, purchase some blessed objects from the prayer centres, participate in a weekend or a weeklong crusade where offerings are frequently collected and invite a pastor to one's house for special prayers for which one has to pay heavily. Usually, the uninformed succumb to these pressures because they are in dire need of a 'break-through' in their lives and because 'blessing is understood as a world-transforming act which cannot be denied' (Brueggemann 2010:227-228). Rebekah's insightful action in Genesis 27 is often cited as a model of one who hunts for blessing and succeeds.

\section{Conclusion}

Human beings have varied ways of expressing their perception of the divine-human relationship. The Biblical concept of blessing, with special attention to the deathbed parental blessing narrated in Genesis 27, offers us a good example of this. God blesses; human beings also bless and in doing so recognise God as the principal agent of blessing. When human beings bless, it is still God who is bestowing his blessing on his creatures. 
We praise God when we bless another person because the components in the human act of blessing are God's gift, proceeding from him alone.

The story of how Isaac blessed his younger son, Jacob, even though his intention was to confer blessing on the elder son, Esau, bears all the salient characteristics of blessing in the OT. His words of benediction, for instance, are cast in a poetic form; and this human agent avowed God as the source of the blessing. The narrative might have some specific significance for its original audience, especially in the fundamental role played by Isaac's wife, Rebekah; our interest in this study focusses on the act of blessing contained therein.

An analysis of the text in the context of the popular Christian understanding of blessing in our contemporary society elicits an aberration in concept and in praxis. When God blesses, he does so not because human beings merit it, nor can human beings exchange their affluence with divine blessings. Religious leaders who induce others to procure divine blessings have ulterior motives that are not far from selfish interests prompted by their ardent desire for self-aggrandisement.

\section{Acknowledgements}

The authors humbly thank the entire team of HTS Journal.

\section{Competing interests}

The authors have declared that no competing interests exist.

\section{Authors' contributions}

M.J.O. carried out the research. F.U. assisted with appropriate literature.

\section{Funding information}

This research received no specific grant from any funding agency in the public, commercial or not-for-profit sectors.

\section{Data availability statement}

Data sharing is not applicable to this article as no new data were created or analysed in this study.

\section{Disclaimer}

The views and opinions expressed in this article are those of the authors and do not necessarily reflect the official policy or position of any affiliated agency of the authors.

\section{References}

Alter, R., 2008, The five books of Moses: A translation with commentary, p. 140, W.W. Norton and Company, New York.

Arnold, B.T., 2009, Genesis, The New Cambridge Bible Commentary, p. 246, Cambridge University Press, Cambridge.

Birch, B.C., Brueggemann, W., Fretheim, T.E. \& Petersen, D.L.A., 2005, A theological introduction to the Old Testament, Abingdon Press, Nashville, TN.

Brown, W.E., 1996, 'Blessing', in W.A. Elwell (ed.), Baker's evangelical dictionary of biblical theology, Baker Book House Company, Grand Rapids, MI, viewed 05 June 2018, from https://www.biblestudytools.com/dictionaries/bakers-evangelicaldictionary/blessing.html.

Brueggemann, W., 2010, Genesis, Interpretation: A Bible commentary for teaching and preaching, Westminster John Knox, Louisville, KY.

Bulka, R.P., 1990-1991, 'The selling of the birthright, making sense of a perplexing episode', Jewish Bible Quarterly 19, 100-104.

Canlish, R.S., 1979, Studies in genesis: Expository messages, Kregel Publications, Grand Rapids, MI

Champlin, M., 2017, 'A biblical theology of blessing in genesis', Themelios 42(1), viewed 30 October 2018, from http://themelios.thegospelcoalition.org/article/abiblical-theology-of-blessing-in-genesis.

Dachen, I., 2016, '5 reasons Nigerians are so religious', viewed 21 September 2016, from https://www.pulse.ng/gist/pulse-list-5-reasons-nigerians-are-so-religious/ $64 \mathrm{ph} \times \mathrm{n} 5$.

Gerstenberger, E.S., 2002, Theologies in the Old Testament, Fortress Press, Minneapolis, MN.

Goodnick, B., 1995, 'Rebekah's deceit or Isaac's great test', Jewish Bible Quarterly 23, 221-228.

Izuekwe, C., 2011, 'Pastor, wife docked for duping widow', viewed 11 May 2019, from https://www.pmnewsnigeria.com/2011/08/02/pastor-wife-docked-for-dupingwidow/.

Joüon, P. \& Muraoka, T., 2006, A grammar of Biblical Hebrew, Editrice Pontificio Istituto Biblico, Rome.

Keller, C.A., 1997, 'Brk, to bless', in E. Jenni \& C. Westermann (eds.), Theological dictionary of the Old Testament, vol. 1, pp. 266-282, transl. M.E. Biddle, Peabody, Hendrickson, MA.

Matthews, V.H. \& Benjamin, D.C., 1997, Old Testament parallels: Laws and stories from the ancient near east, Paulist Press, New York.

McKenzie, J.L., 1965, 'Bless, blessing', Dictionary of the bible, p. 98, The Bruce Publishing Company, Milwaukee, WI.

Moberly, R.W.L., 2009, The theology of the book of Genesis, Old Testament Theology, p. 168, Cambridge University Press, Cambridge.

Mösch, T., Bello, M.B. \& Hoffmann, G., 2007, 'Promises of miracles attract millions to Nigeria's churches', viewed 13 September 2007, from https://www.dw.com/en/ promises-of-miracles-attract-millions-to-nigerias-churches/a-2780202.

Otzen, B., 1986, 'țal', Theological dictionary of the Old Testament, vol. V, pp. 323-330, Eerdmans, Grand Rapid, MI.

Pritchard, J.B. (ed.), 1969, Ancient near eastern texts relating to the Old Testament, Princeton University Press, Princeton, NJ.

Rackman, J., 1994, 'Was Isaac deceived', Judaism 43, 37-45.

Raymond, I., 2016, 'Thoughts on the abuse and corruption in Nigerian churches, and why religion cannot reform the world', viewed 11 May 2019, from http:// saharareporters.com/2016/01/12/thoughts-abuse-and-corruption-nigerianchurches-and-why-religion-cannot-reform-world.

Scharbert, J., 1999, 'brk, berākhāh', Theological dictionary of the Old Testament, vol. 11, pp. 279-308, Eerdmans, Grand Rapid, MI.

Snijders, L.A., 1991, 'Genesis 27: Het bedrog van Jakob (Genesis 27: The Deceit of Jacob)', Nederlands Theologisch Tijdschrift 45(3), 83-192.

Uval, B., 1998, 'The Dew of Heaven (Gen 27:28)', The Jewish Bible Quarterly 26, 117-118.

Waltke, B.K. \& O'Connor, M., 1990, An introduction to biblical syntax, p. 652 , Eisenbrauns, Winona Lake, IN.

Watson, W.G.E., 1995, Classical Hebrew poetry: A guide to its techniques, Sheffield Academic Press, Sheffield.

Wenham, G., 1994, Genesis 16-50, Word Biblical Commentary, vol. 2, p. 209, Thomas Nelson Publishers, Nashville, TN.

Westermann, C., 1985, Genesis 12-36: A commentary, transl. J.J. Scullion, pp. 440-441, Augsburg Publishing House, Minneapolis, MN.

Zucker, D.J., 2011, 'The deceiver deceived: Rereading Genesis 27', Jewish Bible Quarterly 39(1), 46-47. 